Marquette University

e-Publications@Marquette

$1-1-2016$

Insights for Prevention Campaigns: The Power of Drinking Rituals in the College Student Experience From Freshman to Senior Year

Joyce M. Wolburg

Marquette University, joyce.wolburg@marquette.edu

Accepted version. Journal of Current Issues \& Research in Advertising, Vol. 37, No. 1 (2016): 80-94.

DOI. (C) 2016 Taylor \& Francis (Routledge). Used with permission. 


\title{
Insights for Prevention Campaigns: The Power of Drinking Rituals in the College Student Experience From Freshman to Senior Year
}

\author{
Joyce M. Wolburg \\ Department of Strategic Communication, Marquette University, \\ Milwaukee, WI
}

\begin{abstract}
Using a ritual behavior model and in-depth interviews, this qualitative study examined the role of alcohol in the lives of college students as they transitioned from freshmen to senior year. Key differences in the drinking ritual emerged across the four years, and insights were noted in students' use of alcohol to form a community of friends, to find order in their lives, and to transition from ill-at-ease adolescents to confident adults. A key campaign strategy emerged based on students' desire to avoid being the one who drinks the most or the one who drinks the least.
\end{abstract}

My rule is this: I don't want to be the drunkest guy in the room but I don't want to be the most sober ... Right or wrong, I want to be in that middle 50 or 75 percent. (Kevin)

Binge drinking continues to be one of the most challenging issues facing college campuses. Statistics show that on average 36

Journal of Current Issues and Research in Advertising, Vol 37, No. 1 (2016): pg. 80-94. DOI. This article is @ Taylor \& Francis (Routledge) and permission has been granted for this version to appear in e-Publications@Marquette. Taylor \& Francis (Routledge) does not grant permission for this article to be further copied/distributed or hosted elsewhere without the express permission from Taylor \& Francis (Routledge). 
percent of students binge drink, defined as consuming five or more drinks in a row for men, and four or more drinks for women, at least once in the last two weeks (National Institute on Drug Abuse [NIDA] 2012). This level of consumption typically results in a blood alcohol concentration of 0.08 percent or higher, which is the legal standard of intoxication and can result in serious consequences (Centers for Disease Control and Prevention [CDC] 2012).

While binge drinking is meaningful to students on a number of dimensions and is often regarded as a rite of passage (Boekeloo, Novik, and Bush 2011), it is also associated with a host of problems, including unsafe sex, death, injury, assault, sexual abuse, drunk driving, alcohol abuse and dependence, academic problems, and so on (National Institute on Alcohol Abuse and Alcoholism [NIAAA] 2012). Thus, universities have a vested interest in developing programs that decrease the prevalence of binge drinking in order to reduce harm to students.

Much of the research on college student binge drinkers has segmented various factors that predict heavy drinking with some degree of accuracy (Borsari, Murphy, and Barnett 2007). These include personality traits, such as sensation seeking and willingness to take risks (Stephenson, Hoyle, Palmgreen, and Slater 2003); race and ethnicity (O'Malley and Johnston 2002; Del Boca et al. 2004); gender (Adams and Nagoshi 1999; O'Malley and Johnston 2002); religion (Weitzman, Toben, and Wechsler 2003; White et al. 2006); previous history of drinking (Grekin and Sher 2006); and membership in fraternities and sororities (Borsari and Carey 1999; Bartholow, Sher, andKrull 2003). Although much is known about the characteristics of the heaviest drinkers on college campuses, finding effective solutions to the problems of binge drinking remains a challenge.

A number of studies focus on drinking as part of the freshman experience (Borsari, Murphy and Barnett 2007), and typically show that first-year students have certain expectations about alcohol consumption-both positive and negative. Students are likely to drink more heavily when positive expectancies outweigh negative ones (e.g., that drinking will reduce stress, overcome inhibitions, promote openness in social situations, and lead to physical and social pleasure, 
vs. leading people to say and do things they will later regret). Alcohol expectancies are among the most robust predictors of alcohol consumption in the first year (Del Boca et al. 2004; Greenbaumet al. 2005).

Research into the motivations of college freshmen shows that making friends and fitting into the social scene are key drivers for heavy alcohol consumption, particularly since students perceive heavy drinking as the route to popularity (Maggs 1997).Compared to nondrinkers, students who drink actually have more friends (Moffat 1991) and are rated as more popular by their peers (Ashmore, Del Boca, and Beebe 2002). Thus, the association between heavy drinking and popularity is fact rather than fiction. Unfortunately, as many as 77 percent of college student drinkers consume alcohol with the intent of getting drunk, which heightens the risk of serious consequences (Boekeloo, O'Novik, and Bush 2011). Furthermore, because students are in a transitory stage in their lives, they often feel they are exempt from standards of conduct that govern people who are not in transition (Turner 1969). Crawford and Novak $(2010,71)$ confirmed the perception among undergraduates that they occupy a "unique, albeit temporary, status that enables them to drink irresponsibly with few negative consequences." In particular, students with high scores on the BACE index (Beliefs about Alcohol and the College Experience) were more heavily influenced by social drinking norms on campus than those with low BACE scores. These students held certain beliefs, such as that college is the best time in their life for drinking, alcohol excuses bad behavior, and drinking makes for the best stories/memories of college life (Wolburg 2001; Crawford and Novak 2010).

During the time students spend at four-year institutions, most turn 21 years of age and transition from underage drinker to legal drinker. Although alcohol is readily available to underage drinkers through private parties, Greek events, and bars (for students with fake IDs), the ease and ability to purchase alcohol increases dramatically when they turn 21 . For this reason, some university administrators expect college students to increase consumption upon becoming legal drinkers. However, because alcohol is no longer "forbidden fruit" to students of legal age, others expect alcohol consumption to decrease. 
In a comprehensive study of drinking behavior before and after turning 21, Fromme, Wetherill, and Neal (2010) found that the frequency and quantity of alcohol consumption increased from ages 18 to 21 while the quantity per drinking occasion decreased between ages 21 and 23-a finding that is consistent with earlier studies (Pederson and LaBrie 2007; Read et al. 2008). Fromme, Wetherill, and Neal (2010) concluded that heavy consumption during the earlier years is consistent with pregaming and other binge styles of drinking that are more typical of underage drinkers. After students turn 21, they have easier access to alcohol and they "may not feel as compelled to 'preparty" as when they had more limited, illegal access" (25).

Research has examined various environmental approaches aimed at limiting the consumption of alcohol, such as price, availability of alcohol, enforcement of campus alcohol policies, and underage drinking laws (Borsari, Murphy, and Barnett 2007), with easy access to low-cost alcohol and lack of enforcement of policies among the prime factors associated with heavy drinking (Kuo et al. 2003; Weitzman, Toben, and Wechsler 2003). Other approaches attempt to modify behavior by changing social norms (Perkins 2003), and finding safer ways to preserve the ritual functions of alcohol consumption (Treise, Wolburg, and Otnes 1999). Since binge drinking continues to challenge university administrators, it is worth a closer look at these approaches.

\section{Two perspectives for addressing the problem}

\section{Social norms}

The social norms model assumes that risky behavior is influenced by misperceptions about the beliefs and behaviors of peers (Perkins 2003; Thombs et al. 2004). In the context of college student drinking, two concepts help to explain these misperceptions. First, pluralistic ignorance refers to the tendency for students to believe that other students drink more than they actually do (Miller and McFarland 1987). Although nondrinkers and moderate drinkers are typically the majority of students on most campuses, they mistakenly assume that most students drink more than they do (Ott and Haertlein 2002; Thombs et al. 2004). In order to weaken peer influence, social norms

Journal of Current Issues and Research in Advertising, Vol 37, No. 1 (2016): pg. 80-94. DOI. This article is (C) Taylor \& Francis (Routledge) and permission has been granted for this version to appear in e-Publications@Marquette. Taylor \& Francis (Routledge) does not grant permission for this article to be further copied/distributed or hosted elsewhere without the express permission from Taylor \& Francis (Routledge). 
campaigns attempt to assure students that nondrinking or moderate drinking is the actual norm.

Second, false consensus refers to the incorrect belief that others are like themselves (Ross 1977). This leads heavy drinkers to mistakenly believe that most other students drink as much as they do (Thombs et al. 2004). The combination of pluralistic ignorance and false consensus provides a strong justification for heavy drinkers to maintain their high-risk behavior (Perkins and Wechsler 1996).

Interventions on college campuses have typically challenged these misperceptions with messages such as "64\% of ...students have 4 or fewer drinks when they party" (Thombs et al. 2004, 62). This approach has worked well for some colleges, with a 43 percent reduction in binge drinking reported during a six-year period at Northern Illinois University (Haines 1996) and a 29 percent reduction reported over a three-year period at the University of Arizona (Werch et al. 2000). However, a comprehensive study from 1997 to 2001 reported that the thirty-seven institutions using a social norms campaign had no better results in reducing student drinking than the sixty-one institutions that did not (Wechsler et al. 2003).

Thombs et al. (2004) offered three reasons why the social norms approach is sometimes ineffective in reducing bing drinking: The reliance on self-reported data about alcohol consumption can lead to stated norms that are not credible to students; the purpose of the campaign is not readily understood by the student population, many of whom don't discriminate between social norm messages and traditional antidrinking messages; and, finally, the stated norms often lack relevance between the university as a whole and students' own reference groups. Students are more concerned with the drinking norms of their close friends than the norms for the university at large. Thus, university-wide consumption rates may not be a relevant statistic unless they match a student's experience.

\section{Drinking as ritual behavior}

A second framework for understanding the meaning of alcohol consumption among college students is the ritual behavior model.

Journal of Current Issues and Research in Advertising, Vol 37, No. 1 (2016): pg. 80-94. DOI. This article is (C) Taylor \& Francis (Routledge) and permission has been granted for this version to appear in e-Publications@Marquette. Taylor \& Francis (Routledge) does not grant permission for this article to be further copied/distributed or hosted elsewhere without the express permission from Taylor \& Francis (Routledge). 
According to Rook $(1985,252)$, rituals are "a type of expressive, symbolic activity constructed of multiple behaviors that occur in a fixed, episodic sequence, and that tend to be repeated over time." They are "dramatically scripted" and "performed with formality, seriousness, and inner intensity" (252).

By Rook's definition (1985), rituals have four components: (1) a ritual artifact such as alcohol; (2) a script, which describes the rules and procedures to be followed (e.g., how to acquire alcohol, and when and where to drink); (3) the performance of carrying out the ritual for members of the culture (e.g., what drinks to order, how many drinks to consume, how to behave while drinking); and (4) an audience or a significant component of the culture to observe the performance (e.g., other students, bartenders, campus security).

Driver (1991) looked beyond the components of rituals and identified three functions: They provide a sense of community, maintain order, and offer transformation. Treise, Wolburg, and Otnes (1999) investigated the drinking ritual among college students using Driver's model and concluded that organizing the data around the three functions offered powerful insights into the meaning of drinking. The intense group bonding that students gain when they drink together fulfills the community function; the rules that students observe including how, when, and where to drink establish a strong sense of order and security in social situations; and finally, the rite of passage into adulthood attained through alcohol consumption offers a powerful means of transformation.

Given the meaning provided by the drinking ritual, Treise, Wolburg, and Otnes (1999) recommended that public service announcement (PSA) developers encourage students to engage in less risky ways to satisfy the ritual functions of community, order, and transformation without losing the meaning. Asking students to change their consumption patterns will be met with resistance unless the behavior modifications can satisfy the ritual functions. 
NOT THE PUBLISHED VERSION; this is the author's final, peer-reviewed manuscript. The published version may be accessed by following the link in the citation at the bottom of the page.

\section{Method}

This study investigates the role of alcohol in students' transition to college life and examines how the drinking ritual changes as students navigate from freshman year to sophomore, junior, and senior years. By engaging in a qualitative study that privileges the students' point of view, it investigates meaningful rituals that are governed by social norms in hopes of discovering new insights for prevention efforts.

The research was conducted at a private, midsize university in the Midwest. Depth interviews were conducted among thirty student participants who responded to a campus-wide invitation to discuss their alcohol consumption and their transition to college life. Participants were undergraduate students enrolled in various colleges throughout the university, and they met the definition of binge drinker by consuming five or more drinks for men in a single sitting within a two-week period and four or more drinks for women. All interviews were conducted in a university office and lasted about an hour in duration. Students received $\$ 15$ compensation for their interviews.

Although the invitation to participate in the study was open to undergraduates in any year in school, the vast majority of students were entering their senior year, and only one of the thirty participants was under the age of 21 years. Several advantages emerged from interviewing upperclassmen: They could reflect back on their transition to college life as freshmen; they could talk about their experiences as they navigated past their freshman year; and they could speak comfortably because the activity they were discussing was legal. Among the thirty students, there was an even spilt of fifteen males and fifteen females. Two students were African-American, two were Hispanic, and one was an international student. All others were United States-born Caucasians with no identifiable ethnic markers. Only one participant commuted from his parents' home, whereas all others lived in university residence halls during their freshman and sophomore years and moved to apartments/houses for their junior and senior years. 
Questions began broadly about the transition to college life and then narrowed to a discussion of the role that alcohol played in that transition. Additional questions probed how drinking fit their lives as they evolved from freshmen to upperclassmen, and how they transitioned from dorm life, where drinking was illegal and could result in serious consequences, to living off campus, where drinking was easy and legal for students 21 and older. Along the way, they described the ways they obtained alcohol, the meaning of turning 21 , the sense of entitlement for drinking below the legal age, the ways they minimized the risks of getting caught, and the downside to drinking more than their peers, among others.

All interviews were recorded and transcribed, and the constant comparison method of analysis was used to identify common themes (Glaser and Strauss 1967). Most students had remarkably similar experiences with drinking, and after the first twenty interviews, no new themes emerged, which indicated that the data collected from the thirty interviews was sufficient to reach the point of redundancy (Taylor 1994).

The research questions posed were:

RQ1: Among heavy drinkers, what role does alcohol consumption play in the transition to college life?

RQ2: How does drinking ritual evolve as students transition from freshman to senior year? Specifically, how do the ritual functions of community, order, and transformation associated with student drinking change over time?

RQ3: What experiences, if any, offer insights for campaign developers that could be used strategically to persuade student drinkers to discourage binge drinking?

\section{Findings}

\section{Alcohol and the transition to college life (RQ1)}

\section{Forming a community}

When asked about the role of alcohol as they transitioned to college life, most students spoke of the desire to bond with other 
students. Many of the participants recalled their excitement over leaving home and embarking on a new chapter of their lives, but they also spoke of the loneliness and uncertainty that came with independence. Drinking helped them make connections with others as quickly as possible at a time when they felt alone and in need of connecting with others. Ultimately, the transition to college created the desire to make friends as quickly as possible, and the easiest way to make friends was to drink.

The participants reflected on their freshman year as one when they cast a wide net to meet as many new people as possible, which means never turning down an invitation to a party. As one student put it, "Drinking is the college experience. It's what you do. You party." The comment that follows speaks not only to the ease inmaking friends because they have so much in common, but also the pressure students feel to make friends quickly during the first weeks of the semester. Failing to make friends at that critical period can jeopardize one's social life in the future.

During orientation week as freshman you go to a party and it's all people your age, all people who are looking to make friends. And you know they're the type of people who are going to want to do things and experience college.

...The first few months are just so important to meet people because after the first few months, people are going to have their friends and they won't be as open to meeting new people. (Kate)

The need to make friends quickly has a certain quality of desperation, and some discovered that these initial relationships were built on convenience rather than shared interests. The only thing they had in common with each other was drinking.

Friend scramble. That's what I call it. During orientation week everyone is so alone that they're just trying to latch onto whoever is next to them, and it's just like you form this friendship that has no basis. But it's just like I need to know somebody, so let's be friends and that's kind of what it is. (Louisa) 
The drinking ritual is so strong that it not only provides bonding moments during the time of consumption but afterward in the reliving of the event through storytelling. One student described the drinking scene as a contest regarding who had the wildest night or was the most out of control. "It was like a competition of who could have the best story the next day."

Although many students look forward to being part of the drinking scene and are not overly concerned about the consequences, some are worried about the risks they take. These students don't particularly want to be part of the drinking culture but don't see a way to avoid it because the benefits outweigh the risks. One student who didn't drink in high school entered college feeling naive and vulnerable to peer pressure.

The nature of the college puts you in a vulnerable position like, "oh you don't drink, that's not cool." I remember being really scared. It was, like, this party scene is not for me. It was SCARY. It's illegal, so I always had this fear in the back of my head that my parents would kill me if I got in trouble...It was hard because I did want to make friends and I did want to go out, so I had to find the balance between going out and studying. Standing up to your friends is difficult. (Liz)

Similarly, some students are very focused on doing well academically and struggle to balance their time and energy between drinking and studying. One participant was quite intent on being a good student in his freshman year but gave in to the temptation to drink heavily because "when you're drunk, you're talking to people, you're socializing, you seem popular. So you think, oh this is great, I can do this every night (and still do well academically) and I'll have plenty of friends by end of the semester."

My parents would say, "You have to be a good student in college." So that was also part of the reason why I didn't party as much my freshman year, but once I started making these friends, they served as an influence towards partying more. They would say "Hey, man, it's OK," like "I've got friends that party all the time, they've got a 4.0 or have been scholars, so you could party if you wanted to, just make sure you wake up for class." Once I started meeting people who party more, they could easily influence me. (Joe)

Journal of Current Issues and Research in Advertising, Vol 37, No. 1 (2016): pg. 80-94. DOI. This article is (C) Taylor \& Francis (Routledge) and permission has been granted for this version to appear in e-Publications@Marquette. Taylor \& Francis (Routledge) does not grant permission for this article to be further copied/distributed or hosted elsewhere without the express permission from Taylor \& Francis (Routledge). 
NOT THE PUBLISHED VERSION; this is the author's final, peer-reviewed manuscript. The published version may be accessed by following the link in the citation at the bottom of the page.

\section{Establishing order}

Since drinking is an illegal activity for underage students, the question arises as to how, when, and where they drink. Most of the drinking was on weekends; however, the weekend often stared on Thursday and in some cases on Wednesday. Sunday was not a popular night for drinking because most students needed time to recover and catch up on classwork. As one student put it, "Sunday is hangover day. You can tell who had fun the night before just by seeing all the people moving slowly and drinking lots of water and coffee."

Dorms. Because freshmen have limited access to alcohol, their main choices for where to drink are dorms, house parties, bars, or private parties, and each option has its own set of rules for how to drink. Drinking in the dorms requires students to smuggle in alcohol and drink behind closed doors. Concealing hard liquor in a backpack and mixing it with soda or other beverages in the room is relatively easy; however, students need a complex set of skills regarding how to party without being caught, including knowing when the resident assistants (RAs) make rounds and when the desk receptionist is more likely to do a random search of backpacks.

I've been written up before for drinking in the dorms. They watch that closely. If your music is too loud, if they hear someone talking about drinking, if they hear someone yelling, even if they smell it. Because it's university property, the RAs can just go in your room because it's not your room. It's on everyone's mind. It's definitely a concern. (Paul)

Most drinking in the dorms is in the form of "pregaming"drinking before drinking elsewhere. On a typical night, students might start drinking at $8: 30$ or $9: 00$ and then go to a party at 10:30 or 11:00. The participants found that pregaming was not only a way of making friends with those who live in the dorm but also a way of cutting down on the cost of alcohol. Although students are concerned about getting caught, many feel little to no remorse about breaking the rules. Instead, they feel entitled to drink because they regard the legal drinking age as unfair and unrealistic. Furthermore, the need to align themselves against the authorities gives them a common goal 
that strengthens the bond between them. Several students commented on the appeal of pregaming.

Sometimes the party will run out of beer ... so it's just easier to drink hard alcohol before going out. It gives you time to get ready with your friends before going to a bigger party. Especially with bars, if you drink beforehand, you're spending less money because you're not buying drinks, you're just going there for the atmosphere. It's cost effective. (Eric)

One downside to pregaming is that students sometimes drink so heavily that they are too intoxicated to go out afterward.

Freshman year, I feel like people end up just pregaming so hard and then passing out in their room. They may be too drunk to go out, or they just can't find a party so they end up drinking in the dorm. Then they go to Qdoba or Jimmy Johns, getting something to eat, hence the freshman 15. (Martha)

One student took the chance of a high-risk venture in order to establish an identity for himself among his peers in the dorm. "It's all about whether people know who you are" because being known is almost the same as being friends.

I remember one weekend we snuck a keg into the dorm, and that almost ended badly. We convinced someone we were moving stuff in so we got a rolly cart, and we threw the keg on there and a back pack to make it look like luggage, and we took it up and put it in my friend's room ... It made me a lot of friends who are still my friends. When people heard, it was all over that we had a keg in the dorm, and a lot of people would come in to get a beer. (Jake)

The consequences for getting caught in possession of alcohol are significant enough to discourage drinking in the dorms; however, students argued that is the safest place for them to drink because they are not on the streets, not driving, and have easy access to help in an emergency. Most students said that despite the university's efforts to prevent drinking in the dorms, it is inevitable.

House parties. Another option for freshmen is drinking at a house party. Students attending the party pay an entrance fee-typically 
\$5-and get a cup that can be refilled until the beer runs out. Anyone can attend, even if they do not know the people giving the party.

It was really exciting to come here, especially as a freshman. There were about 500 people going to house parties. That's probably an exaggeration, but just shoulder to shoulder. I think alcohol played a big part of everyone's experience from day one just because that's what everyone did. (Josh)

House parties are appealing to freshmen because they have limited options for obtaining alcohol and are also appealing to upperclassmen hoping to earn "easy" money by hosting a party. However, the students giving the parties take the risk of being punished for illegally selling alcohol to underage drinkers without a license, and can lose money on expensive repairs for damages if the party gets out of hand.

During orientation there are a lot of parties because juniors and seniors know that they can make money off of freshmen by just buying one keg ... You go to the front door and they say its $\$ 5$ a cup. One of the guys that lives nearby said they made like $\$ 300$ off of it, so people just like to do it to make rent money. (Bryan)

Bars. A third option for freshmen is bars, but they need to avoid ones that "card hard." For some universities, bars at a greater distance from campus are easier for underage drinkers to get into. Most students who frequented bars acquired a fake identification (ID), either by paying to have their own made or by simply borrowing the legal ID of another student. They hoped that the bouncer wouldn't pay too much attention to the person's photo and would only notice the birth date.

I mean that was the biggest, the most talked about conversation freshman and sophomore year-oh what fake ID do you have, where did you get it from, how much did you pay? Does it work or where does it work? Because there would always be stories of places people could get into. (Ryan) Almost all of my friends that I consistently go out with have fake IDs, but there are some bars that don't really card. Like this one bar that we go to a lot, we know the bouncer so if we have an extra person along that doesn't have an ID, they'll just kind of let it slide. (Alex) 
Like drinking in the dorms, getting into bars means thinking strategically and knowing how to play the game. The adventure of getting into a bar illegally adds to the fun and is a sign of ingenuity and craftiness. "Once you get in, it just makes the party that much more exciting because you know you aren't supposed to be there and could get kicked out at any moment."

Students who try to get past a bouncer with a fake ID take their chances. Despite their ingenuity, some students lose their ID, their money, or both.

There were places where you knew you couldn't get in, but you could pay your way in. I think the bouncers are paid $\$ 40$ for every fake ID they take away, and typically you can pay the $\$ 40$ and they'll let you in and give you your ID back. But sometimes you can pay the $\$ 40$ and they'll let you in, but they won't give you your ID back. They'll just take your $\$ 40$, your ID, and kick you out. (Jake)

Private parties. The other option for freshmen is attending a private party, usually given by fraternities, club sport groups, friends, or older siblings who live in an apartment. Attending a private party takes the stress out of going to a house party or needing a fake ID.

Freshmen actually frequented the frat parties mostly because that's what stereotypical college is like. They would prey on the freshmen and they would throw all these different themed parties ...I didn't go to a single party junior year but I went to all of them freshman year because I thought they were the best parties in the world. (Sean)

\section{Transformation}

For many incoming freshmen, drinking is the "epitome of being a college student." It defines them and helps to establish a new identity. Although some students drink in high school, it is out of reach for many until college, where drinking to get drunk is often the norm. For freshmen, the act of drinking is a rite of passage that transforms them from adolescents who are still socially ill at ease to adults who are socially adept. Furthermore, the properties of alcohol as a 
NOT THE PUBLISHED VERSION; this is the author's final, peer-reviewed manuscript. The published version may be accessed by following the link in the citation at the bottom of the page.

depressant enhance the transformation by relieving stress and lowering inhibitions, which makes social interaction easier.

As freshmen, we just drink to get drunk and be stupid and just enjoy ourselves because I feel like there is so much to be timid about, and that doesn't exist when you're drunk. Your id just takes over and when you're drunk you lose all of that selfconsciousness. That's the aim that a lot of freshmen and sophomores are going for. Everyone's going to enjoy the party more if you're more relaxed and if everyone's being stupid. (Alex)

Students have an intense desire to belong, and the drinking ritual transforms them to members of a social network. Without alcohol, students fear they may fail to have the social life they want and need.

Alcohol's the confidence booster. It just gives you the confidence to go up and say hey, I'm Bryan, nice to meet you, how are you? And then you would start those typical freshmen conversations like hey, "Where are you from?" and "What's your major?" I attribute most of my friendships to meeting people at parties. Like if I was the kid who stayed indoors, I probably would not have that many friends sophomore or junior year. (Bryan)

Some students who drink find it so central to building a network of friends that opting out of drinking is not a viable option. One student characterized nondrinkers as socially inept people who haven't mastered the social skills they need to succeed.

People who don't drink tend to be sort of weird. You'd have to almost characterize them as the kids who were homeschooled. When you talk to them they're off-putting, they don't understand the nuances of working in a social environment, especially one as complex as the college environment ...I don't want to make broad stereotypes, but stereotypes exist for a reason. You find that students who aren't going out and drinking don't create that large group of friends. They don't have that bond, they don't have the fun that you do in college. If you're not going to those parties, whether you're drinking or not, you're not part of that scene. (Jamie) 


\section{The evolution of the drinking ritual across the years $(R Q 2)$}

\section{Freshman to sophomore year}

During the transition from freshman to sophomore year, drinking remains an illegal activity for most students and they continue to live in residence halls unless they live at home with parents. Yet the drinking ritual changed in several ways during the first two years: The community of drinkers became smaller and more closely-knit over time; the order shifted with more reliance on private parties and bars than house parties; and the transformation they sought was driven by different needs.

One female student recalled that as freshmen, they were searching for not only as many new friends as possible but also the easiest ways to acquire alcohol, given the limitations of being underage. As sophomores, drinking became more about the pleasure of being with friends than about rebelling or getting "trashed."

Freshman year it was all about just getting a hold of this alcohol, getting into these parties and just drinking because you want to, because you're able to, because you're out of the house, and because you're rebelling. All those reasons. You're just drinking to drink.

Sophomore year it's more about bonding with your group of friends. You play more drinking games and you're not trying to just get trashed in 30 minutes. You learn freshman year that's not fun. Sophomore year, you know your group of friends so you're not just trying to find a party, and you're not ripping shots. You have a mixed drink and you're sipping that over an hour when you play this game. It's still a decent amount of alcohol, but you're not trying to get trashed. (Kate)

Many of the participants echoed these thoughts and noted that sophomores are still relatively new to college life but are more confident than freshmen. Most feel less pressure to make new friends because they already have a set of friends, have begun to find a balance between studying and partying, have begun to learn their 
limits when drinking, and have decided which rules can be broken. Many still drink heavily but with a different purpose.

During sophomore year, I just didn't feel the need. I just didn't see the point. We still go out a lot but we've cut back on the number of drinks we have, or if people need to stay in to study, we don't pressure them to go out. At bars you just can't be that drunk because you have to get home. At house parties, you can get as drunk as you want because you're only a couple of blocks away, but at bars you have to get home so you have to be responsible to get home at the end of the night, and that's a cab ride. (Martha)

One student spoke to the transition from drinking in the dorms to bars because several of his friends couldn't afford to be caught drinking in the dorms again. More students had fake IDs by the time they were sophomores, knew someone "legal" who would loan them their ID, or knew which bars were easy to get into without an ID.

There's a lot of going to bars sophomore year because a lot of people didn't want to drink in the dorms because they had been written up. And there is a lot of pressure to be like we're older now and it's cooler to go down to the bars so a lot of kids would choose that over a house party. (Kevin)

\section{Sophomore to junior year}

The transition from sophomore to junior year changes the drinking ritual dramatically in a number of ways. First, the community of drinkers becomes even more defined and closely knit. Second, the move from dorms to apartments or houses changes the ordering function of drinking, with not only the freedom from rules but the ability for juniors to host the house parties that freshmen attend. Third, the transition from illegal to legal drinker brings about a complex transformation, given that students turn 21 at different times during the year. Many students still drink heavily but are not as desperate to get drunk and can turn down a party if it doesn't interest them.

Several students spoke to the greater comfort with their friends. They realize that some of the friends they had during their first two

Journal of Current Issues and Research in Advertising, Vol 37, No. 1 (2016): pg. 80-94. DOI. This article is (C) Taylor \& Francis (Routledge) and permission has been granted for this version to appear in e-Publications@Marquette. Taylor \& Francis (Routledge) does not grant permission for this article to be further copied/distributed or hosted elsewhere without the express permission from Taylor \& Francis (Routledge). 
years were merely friends of convenience, and that their real friends are a smaller, more closely knit group who share common interests.

Sure the parties are smaller than they were freshman or sophomore year, but you're surrounding yourself with people you're most comfortable with. Instead of hanging around with those big, packed parties, where there are going to be hundreds of people that you say hi to, you're out grilling in the back yard, drinking beer with thirty or forty of your friends. And if you go to the bars, you're only hanging out with those twenty or thirty people. (Paul)

One student spoke about the freedom from dorm life-not having to worry about someone checking her backpack when she come back from class-and the change in relationships that came about by the move to off-campus housing. She no longer had something to prove, for she had been there, done that.

By junior year you're able to drink and not get in trouble by your RAs. Your friends have houses, your friends have apartments, you always have people you can call and be like, hey do you want to hang out here for a while? And it would be that group of friends you made freshman year by going out and everyone ending up at the same sort of parties. By then you become more picky ... I don't want to hang out with these randoms-if that's the only party tonight, I'm just not going out. (Kyra)

The dynamic of apartment living changed the order of the ritual by offering not only the freedom from worry over being caught drinking in the dorms and listening to loud music but also the flexibility of staying in or going out later. Living off campus also opens up the opportunity to give house parties and earn money from the freshmen seeking easy access to alcohol. However, this becomes problematic when there are eighty freshmen in an apartment, who are each texting five friends and telling them "come to this place. It's sweet."

During their junior year most students turn 21 years of age, but when their birthdays happen over several months, the timing can divide those who are of legal drinking age from those who are not. The under-21 group gets left behind when the legal drinkers go to bars, and a certain amount of envy is inevitable. Thus, the transformation 
NOT THE PUBLISHED VERSION; this is the author's final, peer-reviewed manuscript. The published version may be accessed by following the link in the citation at the bottom of the page.

function of the ritual happens unevenly across time and can put stress on the community.

When it got to be summer and 80 percent of the people were 21 , it started to suck for me. It's not like I was angry at them-I would get rejected from bars that they all get into and I'd go home and get pissed off. Like it's such a dumb rule. Now I'm 21 and I was at a bar last night, and I texted one of my friends to tell him I didn't think anyone is bouncing right now and he said, "I'm not even going to try." He was playing the pity party role. It kinda sucks for some people. They can't go where the rest of us go. (Alex)

The night that a student turns 21 is usually a significant, longawaited event that is celebrated with many ritual acts. Several students partied during the evening before turning 21 and then went to one of the nearby bars at midnight to be welcomed into the fold of legal drinkers.

I went out at midnight on the morning of my birthday with a couple of people. I'm older than most of my friends so there were not a lot of people who could go out with me because they weren't 21 yet. But when you go at midnight, a lot of bars have specials and give you free shot, will give you t-shirt, will give you a cup, something to say, hey, you celebrated your birthday at this bar and then you are like advertising that everyone goes there for their birthday. (Jamie)

For other students, the heavy drinking usually associated with turning 21 creates a stereotype to live up to and gives them a free pass to drink as much as they can.

If you're out drinking on your 21st, you want people to think that you are drinking a lot. If you're not, you're like breaking the stereotype ... you definitely get a free pass when you turn 21 . You get marks on your arm for every shot you take. At least, that's what happened to me on my birthday ...I took 32 shots on my 21st birthday night, so I have marks on my arm all the way up to here. To be honest, most of my friends can't drink as much as I can, but the goal is like you're supposed to get to 21 for your 21st birthday. (Sean)

Journal of Current Issues and Research in Advertising, Vol 37, No. 1 (2016): pg. 80-94. DOI. This article is (C) Taylor \& Francis (Routledge) and permission has been granted for this version to appear in e-Publications@Marquette. Taylor \& Francis (Routledge) does not grant permission for this article to be further copied/distributed or hosted elsewhere without the express permission from Taylor \& Francis (Routledge). 
Other participants agreed that students get a free pass on birthdays, and there is greater forgiveness for behavior that friends might not otherwise tolerate. One student commented on the bonding between friends and the gratitude she felt for having a friend who "has your back."

This is a weird rule, but it doesn't matter what age you are turning-18, 19,20,21-you can get as drunk as you want and your friends will take complete care of you. Anything can happen, and your friends will be like oh it's their birthday. It's a freebee. On my birthday, one of my friends took my contacts out and put me to bed. That is the sort of things friends will do. It is unbelievable. As many bad things people can say about college and drinking, I will never forget what she did for me on my birthday by taking out my contacts and getting me to bed safely. Your friends will just be like drink as much as you want, I got your back and that's it that's all it takes. (Kyra)

\section{Junior to senior}

The transition from junior to senior year is more subtle than other transitions. Almost all seniors are of legal drinking age, and the tightly knit communities of friends can move past the tension created by students turning 21 years of age at different times. The order becomes firmly established since seniors can drink at any bar, go out any night of the week, and drink without stress. And the transformation reflects students' awareness that they will soon graduate and move into the world beyond college.

So because this is my last year of college, drinking is not one of my priorities. I could care less about getting drunk or getting tipsy before a social gathering. As of now, my priority is that to do well on that DAT test and to get good grades this upcoming year, to boost up my science GPA, and to then to apply dental school. I want to get on with my future. I still have time for friends, we'll still have bonfires, and we'll do some social drinking but I won't let that take away my studying time ...it's time to buckle down and grow up a bit. (Joe)

Many students agreed that by their senior year they drank less. One said his drinking decreased when he turned 21 because he was 
too old to party with "underagers" but too cheap to go to a bar to buy his own alcohol.

So like freshman and sophomore year you probably drink the most, junior year, you probably sit back and try to relax. You don't need to get this drunk, and you don't need to blackout anymore. As much as I do love the social aspect and the taste of drinking, by senior year I felt like it's just kind of one of those things that will fade out of your life as not important. (Bryan)

Although the maturity factor brings about reduced drinking for many students, the need to make the most of the remaining time with friends before graduation can provide a strong motivation for drinking among others.

We may study hard but when we have time, we'll party hard too. It'll be a real condensed form of fun, you know, but we'll pull out all the stops. Everyone's gonna be graduating, too, so everyone spends as much time with people as they can. (Jamie)

One final comment about the senior year is a reflection of life on a college campus and the lack of responsibilities in comparison to those that students will face after graduation.

It's so surreal. It's like being in a bubble. You have a lot of responsibilities but you really don't have that many. All my friends understand that once you graduate you gotta cut out drinking and smoking cigarettes. That's gotta stop. I think most of these guys realize that. And college is one of those times when you work hard and party hard. And you don't have a lot of immediate responsibilities. Most of my friends, we hold jobs, we have internships, and we maintain grades, decent GPAs, but it's kind of a surreal bubble, and all these things are kind of secondary to the college experience. (Kevin)

\section{Insights and strategies for intervention (RQ3)}

The third research question probed for insights that could be used strategically for prevention campaigns. One of the most interesting findings is that some students look upon certain drinking behavior as unacceptable, and there are lines that shouldn't be crossed. A theme that ran throughout many of the interviews was "you 
don't want to be the one who drinks the least, and you don't want to be the one who drinks the most."

When compared to others within a student's social group, drinking at either extreme is undesirable. Drinking the least exposes students to peer pressure, creates an uncomfortable situation, and is simply not a good experience when socializing with heavy drinkers. As one student put it, "There will be guys who drink so heavily that if you're not at least a little drunk when you're around them, it's not fun." Likewise, the uninhibited, heavy drinkers won't find the light drinkers much fun at a party either.

My rule is this: I don't want to be the drunkest guy in the room but I don't want to be the most sober in the room. Right or wrong, I want to be in that middle 50 or 75 percent.

When you're the least drunk-and I was completely sober recently because I had an exam to study for-I felt left out. It's like a joke that you don't get. (Kevin)

At the other extreme, drinking the most can make students a liability to their friends if they lose control, get sick, start a fight, need help getting home, and so on. Knowing they can cross a line creates the fear that they will be judged. "You don't want to get sloppy because you don't want to get friends angry at you."

The person who drinks the most is a hassle sometimes. And when you think you drank the most, you get paranoid that everyone is judging you. If you are really drunk, someone will say to you, "how drunk are you?" And then you get selfconscious. (Bryan)

Losing control is not easily forgiven by some students and can do lasting damage to a reputation. Typically, students don't object to heavy drinking per se, but they draw the line when a friend forces them to take responsibility for their safety because few students want the burden of being the caretaker.

People just don't want to go out with you, they're like you're drinking too much, you're just not fun anymore. You've surpassed fun and gone into crazy ... I have a friend who I am 
NOT THE PUBLISHED VERSION; this is the author's final, peer-reviewed manuscript. The published version may be accessed by following the link in the citation at the bottom of the page.

still hesitant to go out with because one night we had to carry her home. I was staying in that night and someone calledme to go pick her up and take her home. And being stone cold sober, I saw how she was. Now I don't want to go out with her. (Kyra)

Students frequently spoke of friends who were alienated because they were too difficult to manage. Once they crossed the line within their own group of friends, it was hard to be accepted back. One student reflected on a friend who had little tolerance for alcohol and repeatedly tried to keep up with the other drinkers.

He ends up getting drunk really quick. We started to notice itmore sophomore year. We would all be sitting around having a couple of beers, pregaming, and we would be chilling, listening to music, and he would come in kinda hammered, and start a fight with one of us over something stupid. (Jeff) Freshman year I had this friend, and she loved getting wild but at some point she was a liability. Other friends agreed, and they still won't hang out with her because they decided she was a liability freshman year. They consciously decided, "hey, you're too crazy for me." (Alex)

Students also notice certain archetypes of drinkers who get out of control. One commented on the giggly drunk or the flirty drunk, whereas another remarked on the goofy drunks. "If you see them at a bar,maybe you'll laugh at themor laugh with themand hang out briefly, but you wouldn't go out of your way to be with them. In fact you might go out of your way to avoid them."

Several students acknowledged that on special occasions such as birthdays and holidays friends get a pass for drinking too much. It's when the behavior becomes habitual that it's problematic.

When you go out and you're drinking and you have a handle on yourself, you don't want to be a babysitter all night. And if you're looking after them, that happens sometimes. Special occasions, sure, everyone's entitled to get a little sloppy at some point and that's why you have your friends around you. But if you're doing it every night, that is where the problems arise. (Jack) 
Being the caretaker is more challenging than simply leading to a night of obligation rather than pleasure. In many cases students don't know if or when to intervene. They don't want to take risks if a fellow student needs help, but they are reluctant to get a friend in troubleor get themselves in trouble-by calling authorities. They do their best to help a fellow student who has crossed a line, but when things go badly they can be blamed or feel a great deal of guilt.

It's not really your fault, but it feels like your fault if your friend is drunk and gets arrested. You feel a certain amount of guilt and responsibility. You can't just let them take the fall. (Kevin)

A common misperception of college students is that there are no limits with regard to drinking-that anything goes. However, this is not always the case. The drinkers who engage in extreme behavior within their own social group fall outside of the accepted ritual because drinking either too little or too much prevents them from bonding with other drinkers. The light drinkers are not fun to be around, and the heavy drinkers are to be avoided as a liability. Gender differences also come into play, with female students often expressing greater need for safety concerns than male students.

The extreme drinkers can also disturb the accepted order within their social group. They fail to obey the rules of how much to drink and how to behave while drinking. Finally, they do not make the same transformation that their friends experience if they fall outside the groups' expectations. Such is the case if they don't find the same balance between their academic and social life, or if they continue to drink solely to get drunk when others simply want a relaxing time with friends.

\section{Conclusions}

\section{Summary}

Given the challenges that binge drinking poses to college administrators in keeping students safe from harm, this study searched for a deeper understanding of the role that alcohol plays in the life of a college student. From a ritual behavior perspective, in- 
depth interviews explored the lives of binge drinkers from their transition to college as a freshman through their senior year. While much of the existing research treats college students as a cohesive group throughout the four years, this study investigated differences in the way the drinking ritual changes over the years in college. The study also sought insights that can be used in anti-binge-drinking campaigns.

Through interviews, students told their stories about the role of drinking as they bonded into a tightly knit community of friends. This community also discovered order and security by enacting the drinking ritual on accepted days/nights of the week, in certain places, and by following specific rules governed by access to alcohol. Finally, the community of friends used drinking as a way to enhance the transformation from adolescence to adulthood.

The predominant story these students tell is one of early desperation to make friends, which drives them to acquire alcohol in the easiest way possible. As freshmen they want the widest circle of friends possible, which is facilitated by drinking at large house parties. In later years they choose to bond with a more select group of friends. Thus, they develop a social network that distinguishes between friends of convenience and friends who share common interests. By the time they are seniors, they develop a strong bond with friends and drink together to make the most of the remaining time before graduation.

Over time, students use drinking as a way of organizing their lives. Weekends are consistently the heaviest days for drinking, but the time and place change over the years depending upon where they live and when they turn 21 . Where to drink progresses from house parties, dorms, and fraternity parties in the early years to bars and private parties in friends' apartments/houses in later years. Underage drinking requires mastery of a complex set of skills to avoid negative consequences, and turning 21 is an event that comes with certain expectations, including heavy drinking and a free pass for losing control.

Many students enter college as socially ill-at-ease adolescents seeking an identity as well as an education, and leave as adults ready 
to make their mark in the world. For many, drinking becomes part of the rite of passage that gives them confidence. As freshmen, they drink to get drunk, but eventually they find they no longer have something to prove. As seniors they work hard and party hard, but many freshmen just party.

Along the way, they discover that it is possible to drink too much and become a liability to friends. This is the reality among many drinkers - that you don't want to drink the least and you don't want to drink the most-and it is a meaningful insight as a campaign strategy. What makes it compelling is that it is a social norm but one of a different type than the percentages used in other campaigns. Drinking the most or the least creates a level of anxiety in social settings that is real to students and entirely related to the reference group that the student belongs to; thus, the student defines how many drinks is too much or too little.

\section{Campaign strategies}

This study provides insights into the lives of college student binge drinkers, but a question remains regarding how to best transform insights into messages that could reduce harm. Given the behavioral changes from year to year, one could argue that the bulk of prevention efforts should be directed at incoming freshmen and sophomores, for many of the upperclassmen drink with a different purpose and no longer have anything to prove. For them drinking becomes the means to an end, which is enjoying time with friends, rather than an end in itself. Although many upperclassmen still consume large amounts of alcohol because it's legal and more readily available, they have learned some lessons along the way. They also know their limits and what is tolerated in their group of friends. In contrast, younger drinkers are more likely to see drinking as an end in itself and throw caution to the wind in their efforts to build a community of friends. Their social anxiety may also make them more amenable to messages about fitting in since they are transitioning fromhigh school students to college students, and then from freshmen to sophomores. 
Choosing to target freshmen and sophomores also has the advantage of an easier reach because the students typically reside together in dorms. Messages can be directed one-on-one or through small groups during orientation for new freshmen, as well as through groupmeetings in freshman and sophomore residence halls. Given the popularity of pregaming, programs aimed at curbing drinking in the dorms will reach students at the time and place where they make consumption decisions. Additional efforts on campus and at sporting events could reach a mass audience of students, which would reinforce messages to freshmen and sophomores while also reaching juniors and seniors.

Messages that have the greatest chance of success are those that address the risk of becoming a liability to friends as a result of excessive drinking and should be delivered through storytelling. Using real stories and real comments from other students is the only authentic way to reach an audience known for being jaded, and these are best developed uniquely for each campus. Otherwise, messages will be perceived as coming from the administration and may be looked upon with suspicion.

\section{Future directions}

As a qualitative study, the goal of this research is insight; however, quantitative research can assist in measuring the strength and prevalence of attitudes regarding drinking too much/too little, as well as measuring patterns of behavior by year in school. Research at additional universities can identify patterns that may be unique to one type of campus versus those that exist uniformly across all campuses.

Additional qualitative research can provide rich stories about times when students felt anxiety over drinking too much, which can be incorporated into campaign themes that resonate with students in meaningful ways. 
NOT THE PUBLISHED VERSION; this is the author's final, peer-reviewed manuscript. The published version may be accessed by following the link in the citation at the bottom of the page.

\section{References}

Adams, C. E., and C. T. Nagosh. 1999. "Changes Over One Semester in Drinking Game Playing and Alcohol Use and Problems in a College Student Sample." Substance Abuse 20:97-106.

Ashmore, R.D., F.K. Del Boca, and M. Beebe. 2002. ""Alkie" "Frat Brother," and "Jock": Perceived Types of College Students and Stereotypes About Drinking." Journal of Applied Social Psychology 32:885-907.

Bartholow, B. D., K. J. Sher, and J. L. Krull. 2003. "Changes in Heavy Drinking Over the Third Decade of Life as a Function of Collegiate Fraternity and Sorority Involvement: A Prospective, Multilevel Analysis." Health Psychology 22:616-26.

Boekeloo, B.O., M.G. Novik, and E.N. Bush. 2011. "Drinking to Get Drunk Among Incoming Freshmen College Students." American Journal of Health Education 42 (2): 88-95.

Borsari, B., and K. B. Carey. 1999. "Understanding Fraternity Drinking: Five Recurring Themes in the Literature, 1980-1998." Journal of American College Health 48:30-37.

Borsari, B., J. G. Murphy, and N. P. Barnett. 2007. "Predictors of Alcohol Use During the First Year of College: Implications for Prevention." Addictive Behaviors 32 (10): 2062-86.

Centers for Disease Control and Prevention. 2012. "CDC Fact Sheets." Accessed February, 2012. http://www.ded.gov/vitalsigns/BingsDrinking/index.html.

Crawford, L. A., and K. B. Novak. 2010. "Beliefs About Alcohol and the College Experience as moderators of the Effects of Perceived Drinking Norms on Student Alcohol Use." Journal of Alcohol \& Drug Education 54:69-86.

Del Boca, F. K., J. Darkes, P. E. Greenbaum, and M. S. Goldman. 2004. "Up Close and Personal: Temporal Variability in the Drinking of Individual College Students During Their First Year." Journal of Consulting and Clinical Psychology 72:155-64.

Driver, T. 1991. The Magic of Ritual. New York: HarperCollins.

Fromme, K., R. Wetherill, and D. Neal. 2010. "Turning 21 and the Associated Changes in Drinking and Driving After Drinking Among College Students." Journal of American College Health, 59 (1): 21-27.

Glaser, B. G., and A. L. Strauss. 1967. The Discovery of Grounded Theory: Strategies for Qualitative Research. Chicago, IL: Aldine.

Grekin, E. R., and K. J. Sher. 2006. "Alcohol Dependence Symptoms Among College Freshmen: Prevalence, Stability and Person-Environment Interactions." Experimental and Clinical Psychopharmacology 14:32938. 
NOT THE PUBLISHED VERSION; this is the author's final, peer-reviewed manuscript. The published version may be

accessed by following the link in the citation at the bottom of the page.

Greenbaum, P. E., F. K. Del Boca, C.Wang, andM. S. Goldman. 2005. "Variation in the Drinking Trajectories of Freshman College Students." Journal of Consulting and Clinical Psychology 73:229-38.

Haines, M. 1996. "A Social Norms Approach to Preventing Binge Drinking at Colleges and Universities." The Higher Education Center for Alcohol and Other Drug Prevention. Accessed March , 2014. http://www.socialnorms.org/pdf/socnormapproach.pdf.

Kuo, M., H. Wechsler, P. Greenberg, and H. Lee. 2003. "The Marketing of Alcohol to College Students: The Role of Low Prices and Special Promotions." American Journal of Preventive Medicine 25:204-11.

Maggs, J. L. 1997. "Alcohol Use and Binge Drinking as Goal-Directed Action During the Transition to Post-Secondary Education." In Health Risks and Developmental Transitions During Adolescence, ed. J. Schulenberg, J. Maggs, and K. Hurrelman, 345-71. New York: Cambridge University Press.

Miller, D. T., and C. McFarland. 1987. "Pluralistic Ignorance: When Similarity is Interpreted as Dissimilarity." Journal of Personality and Social Psychology 53:298-305.

Moffat, M. 1991. "College Life: Undergraduate Culture and Higher Education." Journal of Higher Education 62:44-61.

National Institute on Alcohol Abuse and Alcoholism. 2012. "College Drinking." Accessed September , 2013. http://www.niaaa.nih.gov/alcoholhealth/special-populations-co-occurring-disorders/college-drinking.

National Institute on Drug Abuse. 2013. "Monitoring the Future, 1975-2011: Volume II, College Students and Adults Ages 19-50." Accessed May , 2013. www.centurycouncil.org/binge-drinking/statistics.

O'Malley, P. M., and L. D. Johnston. 2002. "Epidemiology of Alcohol and Other Drug Use Among American College Students." Journal of Studies on Alcohol-Supplement 14:23-39.

Ott, C., and C. Haertlein. 2002. "Social NormsMarketing: A Prevention Strategy to Decrease High-Risk Drinking Among College Students." Nursing Clinics of North America 37:351-64.

Pederson, E. R., and J. W. LaBrie. 2007. "Partying Before the Party: Examining Prepartying Behavior Among College Students." Journal of American College Health 56:237-45.

Perkins, H. W. 2003. The Social Norms Approach to Preventing School and College Age Substance Abuse: A Handbook for Educators, Counselors, and Clinicians. San Francisco, CA: Jossey-Bass.

Perkins H.W., and H. Wechsler. 1996. "Variations in Perceived College Drinking Norms and Its Impact on Alcohol Abuse: A Nationwide Study." Journal of Drug Issues 26:961-74.

Read, J. P., M. Beattie, R. Chamberlain, and J. E. Merrill. 2008. "Beyond the "Binge" Threshold: Heavy Drinking Patterns and Their Association With

Journal of Current Issues and Research in Advertising, Vol 37, No. 1 (2016): pg. 80-94. DOI. This article is (C) Taylor \& Francis (Routledge) and permission has been granted for this version to appear in e-Publications@Marquette. Taylor \& Francis (Routledge) does not grant permission for this article to be further copied/distributed or hosted elsewhere without the express permission from Taylor \& Francis (Routledge). 
NOT THE PUBLISHED VERSION; this is the author's final, peer-reviewed manuscript. The published version may be accessed by following the link in the citation at the bottom of the page.

Alcohol Involvement Indices in College Students." Addictive Behavior 33:225-34.

Rook, D.W. 1985. "The Ritual Dimension of Consumer Behavior." Journal of Consumer Research 12 (December): 252-64.

Ross, L. 1977. "The False Consensus Effect: An Egocentric Bias in Social Perception and Attribution Processes." Journal of Experimental Social Psychology 13 (3): 279-301.

Stephenson, M. T., R. H. Hoyle, P. Palmgreen, and M. D. Slater. 2003. "Brief Measure of Sensation Seeking for Screening and Large-Scale Surveys." Drug and Alcohol Dependence 72:279-86.

Taylor, R. E. 1999. "Qualitative Research." In Mass Communication Research, ed. M. W. Singletary, 265-79. New York: Longman.

Thombs, D. L., S. Dotterer, S. Olds, K. Sharp, and C. Raub. 2004. "A Close Look at Why One Social Norms Campaign Did Not Reduce Student Drinking." Journal of American College Health 53 (2): 61-68.

Treise, D., J. Wolburg, and C. Otnes. 1999. "Understanding the Social Gifts of Drinking Rituals: An Alternative Framework for PSA Developers." Journal of Advertising 28:17-31.

Turner, V. W. 1969. The Ritual Process: Structure and Anti-Structure. Ithaca, NY: Cornell University Press.

Wechsler, H., T. F. Nelson, J. E. Lee, M. Seibring, C. Lewis, and R. P. Keeling. 2003. "Perception and Reality: A National Evaluation of Social Norms Marketing Interventions to Reduce College Students' Heavy Alcohol Use." Journal of Studies on Alcohol 64:484-94.

Weitzman, E. R., T. F. Nelson, and H. Wechsler. 2003. "Taking Up Binge Drinking in College: The Influences of Person, Social Group, and Environment." Journal of Adolescent Health 32:26-35.

Werch, C. E., D.M. Pappas, J.M. Carlson, C. C. DiClemente, P.M. Chally, and J. S. Sinder. 2000. "Results of a Social Norm Intervention to Prevent Binge Drinking Among First-Year Residential College Students." Journal of American College Health 49:85-92.

White, H. R., B. J. McMorris, R. F. Catalano, C. B. Fleming, K. P. Haggerty, and R. D. Abbot. 2006. "Increases in Alcohol and Marijuana Use During the Transition out of High School Into Emerging Adulthood: The Effects of Leaving Home, Going to College, and High School Protective Factors." Journal of Studies on Alcohol 67:810-22.

Wolburg, J. 2001. "The Risky Business of Binge Drinking Among College Students: Using Risk Models for PSAs and Anti-Drinking Campaigns." Journal of Advertising 30:23-39.

Journal of Current Issues and Research in Advertising, Vol 37, No. 1 (2016): pg. 80-94. DOI. This article is (C) Taylor \& Francis (Routledge) and permission has been granted for this version to appear in e-Publications@Marquette. Taylor \& Francis (Routledge) does not grant permission for this article to be further copied/distributed or hosted elsewhere without the express permission from Taylor \& Francis (Routledge). 